\title{
RANCANG BANGUN PERANGKAT LUNAK PENUNJANG KEPUTUSAN UNTUK MEMILIH KARYAWAN TERBAIK BERBASIS WEB DENGAN METODE SIMPLE ADDITIVE WEIGHTING (SAW) PADA PT BETA PHARMACON
}

\author{
Karya Suhada $^{1 *}$, Saoman $^{2}$ \\ ${ }^{1}$ Karya Suhada: ${ }^{1}$ STMIK Rosma \\ ${ }^{2}$ Saoman: ${ }^{2}$ STMIK Rosma \\ Email: karya@rosma.ac.id, saoman@mhs.rosma.ac.id
}

\begin{abstract}
The decision-making process is important in work activities at PT Beta Pharmacon, one of which is the assessment of employee performance which is a form of motivation as well as appreciation in the world of work, so with this assessment, an employee will be motivated to always give his best performance. The research method used in this research is the System Development Life Cycle (SDLC) and the system development method uses the Waterfall model. The result of this research is that the existence of a decision making system with a web system is expected to produce a decision making system for the best employee performance appraisal that is efficient and effective that can be accepted by all employees and makes it easier for the company to determine the rankings that make the best employees.
\end{abstract}

Keyword: Decision making, employee performance appraisal, web, Simple Additive Weighting Abstrak

Proses pengambilan keputusan merupakan hal yang penting dalam kegiatan kerja pada PT Beta Pharmacon, salah satunya adalah penilaian kinerja karyawan yang merupakan suatu bentuk motivasi sekaligus apresiasi dalam dunia kerja, maka dengan penilaian tersebut, seorang karyawan akan termotivasi untuk selalu memberikan performa terbaiknya. Metode penelitian yang digunakan dalam penelitian ini adalah System Development Life Cycle (SDLC) dan metode pengembangan sistem menggunakan model Waterfall. Hasil dari penelitian ini adalah suatu sistem pengambilan keputusan dengan web sistem, diharapkan dapat menghasilkan sistem pengambilan keputusan dalam penilaian kinerja karyawan terbaik yang efisien dan efektif yang dapat diterima oleh seluruh karyawan serta memudahkan perusahaan dalam menentukan perangkingan yang menjadikan karyawan terbaik.

Kata kunci: Pengambilan keputusan, penilaian kinerja karyawan, web, Simple Additive Weighting (SAW).

Jurnal Interkom: Jurnal Publikasi Ilmiah Bidang Teknologi Informasi dan Komunikasi

Volume 15 Nomor 03 Bulan Oktober - Tahun 2020 


\section{Article History:}

Accepted 3, November, 2020.

\section{Corresponding Author:}

Nama Penulis, Karya Suhada

Departemen, STMIK Rosma

Instansti, STMIK Rosma

Alamat, J1. Kertabumi No.62 Karawang Barat 41311 Karawang, Jawa Barat.

Email Penulis, karya@rosma.ac.id

\section{Pendahuluan}

Di era perkembangan teknologi berbasis pengetahuan saat ini, sumber daya manusia menjadi salah satu aset yang penting dan berharga bagi perusahaan guna mendukung kegiatan bisnis dan mencapai tujuan perusahaan. Sifat dan pola pikir manusia yang berbeda-beda antara satu dengan yang lainnya menyebabkan perlu adanya perhatian yang spesifik terhadap sumber daya ini. Manusia merupakan sumber daya yang paling bernilai yang memiliki potensi untuk mewujudkan perannya sebagai makhluk sosial yang mampu mengelola dirinya sendiri serta seluruh potensi yang terkandung di alam menuju tercapainya kesejahteraan kehidupan dalam tatanan yang seimbang dan berkelanjutan. Saat ini, perkembangan terbaru memandang sumber daya manusia bukan sebagai sumber daya belaka, melainkan lebih berupa modal atau aset bagi institusi atau organisasi di suatu perusahaan.

Penilaian kinerja karyawan merupakan bentuk motivasi sekaligus apresiasi dalam dunia kerja, maka dengan penilaian tersebut, seorang karyawan akan termotivasi untuk selalu memberikan performa terbaiknya. Penilaian kinerja karyawan tidak hanya memberikan sejumlah manfaat untuk karyawan namun juga atasan dan perusahaan. Penilaian kinerja karyawan akan mampu menumbuhkan iklim kerja yang sehat, karena semua pihak yang terlibat akan mendapatkan masukan berdasarkan evaluasi yang telah dilakukan. Dengan cara ini pula semua pihak yang terlibat bisa saling bekerja sama secara sportif untuk meraih target yang sudah ditetapkan.

PT Beta Pharmacon merupakan satusatunya pabrik farmasi yang ada di Kabupaten Karawang, yang berlokasi di Kawasan Surya Cipta Karawang, Jalan Surya Madya Kav.1 No.18 C, Karawang, Jawa Barat. PT Beta Pharmacon merupakan cabang dari PT Dexa Grup yang merupakan salah satu perusahaan farmasi terbesar di Indonesia. PT Dexa Grup memiliki cabang perusahaan lain, yaitu PT Dexa Medica, PT Ferron International, PT Equilab International, PT Sarana Titan Manunggal dan PT Beta Pharmacon. PT Beta Pharmacon saat ini memiliki jumlah karyawan sebanyak 300 orang yang tersebar di beberapa departemen. PT Beta Pharmacon memiliki struktur organisasi dengan level jabatan terendah yaitu operator dan staff sampai dengan level jabatan tertinggi yaitu Presiden Direktur. Satu tahun sekali PT Beta Pharmacon melakukan penilaian kinerja terhadap para karyawannya.

Jurnal Interkom: Jurnal Publikasi Ilmiah Bidang Teknologi Informasi dan Komunikasi

Volume 15 Nomor 03 Bulan Oktober - Tahun 2020 
Hasil terhadap penilaian kinerja karyawan digunakan untuk pemberian bonus dan kenaikan upah karyawan.

Selama ini, metode penilaian karyawan yang dilakukan PT Beta Pharmacon yaitu dengan melakukan pengisian form yang berbentuk form kertas penilaian yang berisi indikator penilaian yang kriterianya terdiri dari kehadiran, sikap dan perilaku prestasi dan hasil kerja serta proses kerja yang diisi oleh atasan langsung disetiap bagian departemen dan kemudian diserahkan ke Presiden Direktur sebagai pengambil keputusan, sehingga metode tersebut belum dapat memberikan hasil yang diharapkan karena dalam pengelolaan datanya belum tersistematis, dikarenakan banyaknya karyawan yang harus dinilai dan juga performa dalam pengelolaan datanya cukup lama memerlukan waktu selama dua bulan, jadi menyebabkan belum efektif.

Melihat permasalahan tersebut, penulis merancang dan membangun sistem pengambilan keputusan yang dapat menilai karyawan secara cepat dan akurat dengan web sistem, yang mana di dalam web sistem penulis akan menyediakan form-form penilaian meliputi penilaian absensi, produktifitas, sikap dan perilaku yang nantinya setiap atasan di masing-masing departemen langsung input pada aplikasi web tersebut dan tidak perlu di serahkan ke Presiden Direktur karena Presiden Direktur bisa melihat data tersebut pada apilkasi web. Untuk kriteria karyawan kontrak akan masuk pada penilaian karyawan terbaik pada saat sudah satu tahun masa kerjanya dan untuk karyawan tetap akan disamakan agar tidak adanya kecemburuan sosial.

Berdasarkan latar belakang di atas, maka penulis merancang dan membangun sebuah sistem yang berbasis web dengan metode Simple Additive Weighting $(S A W)$ atau di kenal dengan metode penjumlahan bobot yang akan membantu dalam mencari alternatife sebagai alat yang dapat memberikan kemudahan dan efektifitas dalam pengelolaan data. Dalam penelitian terdahulu pada jurnal Siprianus Endro Sri Widodo, Septia Lutfi, Solikhin (Vol. 10 No. 2, Juni 2014 ISSN 19072074 ) yang berjudul sistem pendukung keputusan penilain kinerja menggunakan metode Simple Additive Weighting (SAW) pada PT Indonesia sttel Tube Work dalam pembuatan sistem nya menggunakan bahasa pemrograman vb.net, sehingga harus menginstal beberapa kompter jika ingin menggunakan sistem tersbut. Sedangkan jika menggunakan berbasis web tidak perlu lagi instal di beberapa komputer. Untuk itu penulis mengembangkan penilaian kinerja karyawan terbaik dengan menggunakan berbasis web agar dapat membantu dalam memberikan hasil yang maksimal. Penulis melakukan penelitian dengan judul "RANCANG BANGUN PERANGKAT LUNAK PENUNJANG KEPUTUSAN UNTUK MEMILIH KARYAWAN TERBAIK BERBASIS WEB DENGAN METODE SIMPLE ADDITIVE WEIGHTING (SAW) PADA PT BETA PHARMACON".

\section{Tinjauan Pustaka}

\section{a. Rancang Bangun}

Rancang Bangun (desain) adalah suatu istilah umum untuk membuat atau mendesain suatu objek dari awal pembuatan sampai akhir pembuatan [1].

Menurut Nurlaila Hasyim (2014) dalam [2], rancang bangun adalah penggambaran, perencanaan, dan pembuatan sketsa atau pengaturan dari beberapa elemen yang terpisah ke dalam suatu kesatuan yang utuh dan berfungsi. Rancang bangun juga merupakan kegiatan menerjemahkan hasil analisa ke dalam bentuk paket perangkat lunak kemudian menciptakan sistem tersebut atau memperbaiki sistem yang sudah ada.

Sedangkan menurut Jogiyanto pengertian Rancang Bangun (desain) yaitu tahap setelah analisis dari siklus pengembangan sistem yang merupakan pendefinisian dari kebutuhan fungsional, serta menggambarkan bagaimana suatu sistem dibentuk yang dapat berupa penggambaran, perencanaan dan pembuatan sketsa atau pengaturan dari beberapa elemen yang terpisah ke dalam satu kesatuan yang utuh dan berfungsi, termasuk menyangkut mengkonfigurasikan dari komponen- komponen 
perangkat keras dan perangkat lunak dari suatu sistem[3].

\section{b. Sistem}

Menurut Pratama dalam Prabowo and Syani (2016) dalam [4] Sistem didefinisikan sebagai sekumpulan prosedur yang saling berkaitan dan saling terhubung untuk melakukan suatu tugas bersama-sama. Secara garis besar, sebuah sistem informasi terdiri atas tiga komponen utama. Ketiga komponen tersebut mencakup mencakup software, hardware, dan brainware. Ketiga komponen ini saling berkaitan satu sama lain.

Menurut Azhar Susanto (2013:22) dalam [5] Sistem adalah kumpulan (group) Dari subsistem/ bagian/komponen apapun baik fisik ataupun nonfisik yag saling berhubungan satu sama lain dan bekerjasama secara harmonis untuk mencapai satu tujuan tertentu.

\section{c. UML (Unified Modelling Language)}

UML merupakan singkatan dari "Unified Modelling Language" yang merupakan bagian suatu metode permodelan secara visual untuk sarana perancangan sistem berorientasi objek. Definisi UML yaitu sebagai suatu bahasa yang sudah menjadi standar pada visualisasi, perancangan dan juga pendokumentasian sistem software. Dengan perkembangannya UML telah menjadi bahasa standar dalam penulisan blue print software [6].

UML merupakan bahasa visual untuk pemodelan dan komunikasi mengenai sebuah sistem dengan menggunakan diagram dan teks-teks pendukung [7].

UML adalah salah satu standar bahasa yang banyak digunakan di dunia industri untuk mendefinisikan requirement, membuat analisis dan desain, serta menggambarkan arsitektur dalam pemrograman berorientasi objek. Dengan kata lain UML berarti bahasa pemodelan standar dan merupakan alat komunikasi yang konsisten dalam mensuport para pengembang saat ini [8].

\section{d. Use Case Diagram}

Use case merupakan diagram untuk menggambarkan seluruh aktifitas yang dilakukan oleh sistem dari sudut pandang penggunanya. Diagram ini menunjukkan tentang apa yang dilakukan oleh sistem bukan bagaimana sistem melakukannya [9].

Sedangkan menurut [7] Use Case atau diagram use case merupakan pemodelan untuk kelakuan (behavior) sistem informasi yang akan dibuat. Use Case digunakan untuk mengetahui fungsi apa saja yang ada di dalam sebuah sistem informasi dan siapa saja yang berhak menggunakan fungsi-fungsi itu.

\section{e. Website}

Website atau web atau World Wide Web adalah suatu layanan sajian informasi yang menggunakan konsep hyperlink (tautan). Yang memudahkan surfer (sebutan para pemakai komputer yang melakukan browsing atau penelusuran informasi melalui internet) [10].

Menurut Dian Pranita (2009:15) dalam [11] website juga dapat diartikan sebagai kumpulan halaman yang menampilkan informasi data teks, data gambar atau gerak, data animasi suara, vidio atau gabungan dari semuanya, baik yang bersifat statis maupun dinamis yang membentuk suatu rangkaian bangunan yang saling terkait dimana masing-masing dihubungkan dengan jaringanjaringan halaman.

\section{f. Local Area Network (LAN)}

Salah satu segmen industri komunikasi yang tumbuh dengan pesat sejak tahun 1989-an adalah Jaringan Komputer Lokal (LAN = Local Area Network). Jaringan komputer lokal menghubungkan peralatan yang terbatas pada area geografi yang kecil. Jarak yang sebenarnya dapat dicapai LAN tergantung pada implementasi

Jurnal Interkom: Jurnal Publikasi Ilmiah Bidang Teknologi Informasi dan Komunikasi

Volume 15 Nomor 03 Bulan Oktober - Tahun 2020 
tertentu. LAN menjangkau area lokal yang telah ditentukan, seperti ruang kantor, satu bangunan atau sekelompok bangunan [12].

Local Area Network (LAN)) adalah jaringan komputer yang menyambungkan komputer dalam area terbatas seperti tempat tinggal, sekolah, laboratorium, kampus universitas, atau gedung kantor. Sebaliknya, jaringan area luas (WAN) tidak hanya mencakup jarak geografis yang lebih besar, tetapi juga umumnya melibatkan sirkuit telekomunikasi sewaan [13].

\section{g. Metode Simple Additive Weighting (SAW)}

Salah satu metode penyelesaian masalah MADM (Multiple Attribute Decision Making) adalah dengan menggunakan metode Simple Additive Weighting (SAW). Metode SAW sering juga dikenal istilah metode penjumlahan terbobot. Konsep dasar metode SAW adalah mencari penjumlahan terbobot dari rating kinerja pada setiap alternative dari semua atribut [14].

Menurut Sitompul (2017) dalam [15] Metode SAW sering juga dikenal istilah metode penjumlahan terbobot. Konsep dasar metode SAW adalah mencari penjumlahan terbobot dari rating kinerja pada setiap alternatif pada semua atribut. Metode SAW membutuhkan proses normalisasi matriks keputusan (X) ke suatu skala yang dapat diperbandingkan dengan semua rating alternatif yang ada.

\section{Metode Penelitian}

Metode penelitian yang dipergunakan dalam penelitian ini menjelaskan tentang tahapan-tahapan penelitian, metodologi serta tools yang dipergunakan dalam melakukan kegiatan penelitian.

1. Observasi Awal

Observasi awal merupakan tahapan awal penelitian. Tahap ini merupakan tahap pencarian terhadap permasalahan yang akan diteliti. Permasalahan yang akan dijadikan sebagai topik penelitian merupakan permasalahan yang berulang dan memerlukan penyelesaian.

2. Menetapkan Topik Penelitian

Pada tahap ini, permasalahan yang akan dijadikan dasar penelitian ditetapkan dalam bentuk topik atau judul penelitian supaya penelitian memiliki integritas.

3. Menetapkan Ruang Lingkup dan Obyek Penelitian

Setelah menetapkan topik penelitian dibuatlah ruang lingkup dan obyek penelitian. Tujuan dibuat dan ditetapkan nya ruang lingkup serta obyek penelitian adalah supaya penelitian menjadi terarah, memiliki batasan dalam tahapan pelaksanaan penelitian yang akan dilakukan.

4. Melakukan Studi Pendahuluan

Studi Pendahuluan merupakan tahapan yang dilakukan dengan tujuan untuk mengumpulkan informasi-informasi berkaitan dengan masalah yang akan diteliti, sehingga dapat dapat diketahui keadaan atau kedudukan masalah tersebut baik secara teoritis maupun praktis. Pengetahuan yang diperoleh dari studi pendahuluan sangat berguna untuk menyusun kerangka teoritis tentang pemecahan masalah dalam bentuk hipotesis yang akan diuji kebenarannya melalui pelaksanaan penelitian lapangan. Studi pendahuluan dapat dilakukan dengan studi dokumenter, kepustakaan dan studi lapangan.

5. Membuat Rencana Penelitian

Tahap ini merupakan pedoman selama melaksanakan penelitian. Tujuan dibuatnya rencana penelitian adalah untuk mengungkapkan hal-hal yang berhubungan dengan kegiatan pelaksanaan penelitian.

6. Perizinan Penelitian

Perizinan penelitian dibuat supaya penelitian diketahui oleh pihak-pihak yang terkait, memiliki legalitas dan mempermudah pelaksanaan penelitian terutama dalam hal pengumpulan data.

7. Observasi Lanjutan dan Wawancara 
Observasi lanjutan dan wawancara dilakukan untuk mengumpulkan informasi sebagai dasar dalam penelitian. Dalam kegiataan wawancara, yang menjadi narasumber yaitu: Bapak Damres selaku HRD, Bapak Fany Supra Yoga selaku Supervisor produksi dan Bapak anang selaku karyawan produksi.

8. Analisa Kebutuhan Sistem

Analisis kebutuhan sistem bertujuan untuk menganalisis kebutuhan pemakai sistem perangkat lunak (user) dan mengembangkan kebutuhan $u$ ser.

9. Design

\section{a. Perancangan Proses}

Perancangan proses berupa diagram UML (Unified Modelling Language). Perancangan proses yang digunakan adalah model logika yang mana model logika lebih menjelaskan kepada user bagaimana nantinya fungsifungsi sistem secara logika akan bekerja.

b. Perancangan Tabel

Perancangan Tabel berupa tabel-tabel basis data yang digunakan dalam pembuatan sistem.

c. Perancangan Antarmuka

Perancangan antarmuka adalah tahap yang harus dilakukan sebelum mulai membuat aplikasi. Konsep rancangan dalam merancang antarmuka halaman aplikasi adalah tampilan pada halaman aplikasi yang akan dipergunakan oleh pengguna.

10. Development

Pada tahap development, desain harus ditranslasikan ke dalam kode-kode program. Hasil dari tahap ini adalah program komputer sesuai dengan desain yang telah dibuat pada tahap desain.

11. Implementasi

Pada tahap implementasi, semua tahap dalam perancangan dan pengembangan sistem sudah terpenuhi, sehingga sistem sudah dapat dipergunakan. Pada tahapan ini, aplikasi yang telah dibuat, dilakukan pengujian terhadap fungsionalitas.

12. Penulisan Laporan Penelitian
Setelah rangkaian kegiatan penelitian dilakukan, untuk kepentingan publikasi dan rekomendasi atas hasil penelitian, maka dibuatlah laporan penelitian. Laporan penelitian merupakan tahapan yang sangat penting karena merupakan masukan untuk penelitian penelitian sejenis yang akan dilakukan.

\section{Hasil Penelitian dan Pembahasan}

\section{a. Analisis Prosedur Berjalan}

Identifikasi prosedur ini dilakukan untuk mengetahui sistem yang sedang berjalan pada penilaian kinerja di PT Beta Pharmacon. Dalam hal ini dapat dilihat berupa alur-alur serta arah sistem yang berjalan yaitu:

1) HRD: Membuat form Penilaian dan mengelola dokumen.

2) Supervisor: Mengisi form penilaian

3) Presiden Durektur: Menyetujui hasil rekapitulasi

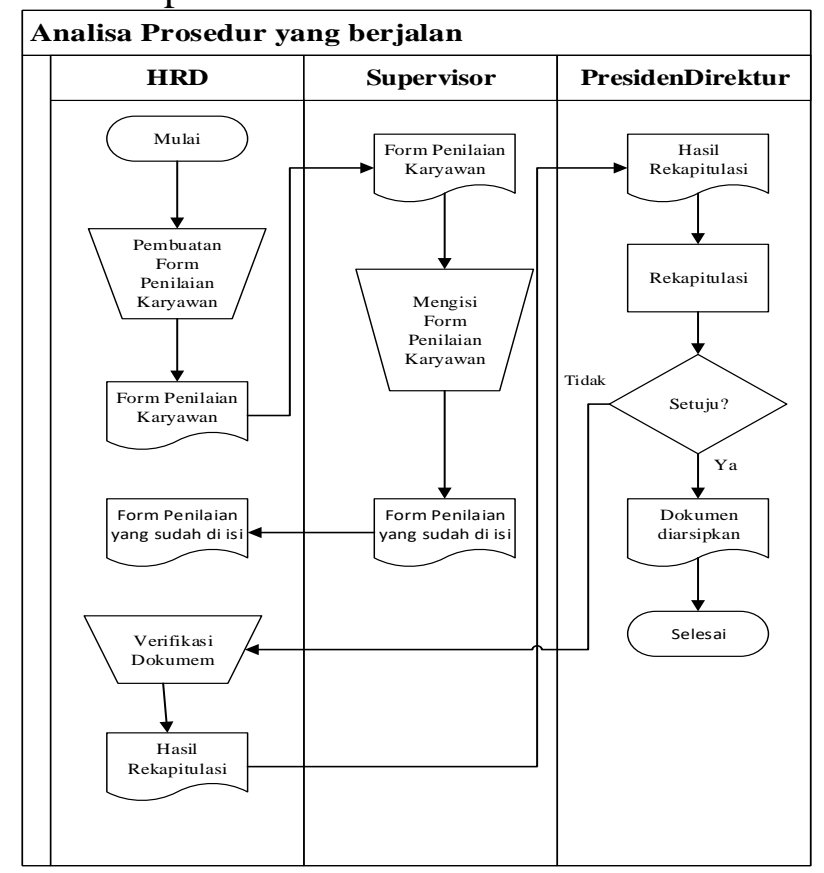

Gambar 1 Flowchart sistem penilain kinerja karyawan yang berjalan 


\section{b. Sistem Prosedur Usulan}

Sistem yang berjalan masih menggunakan sistem perhitungan dengan tulis tangan dan dari sistem yang berjalan tersebut ditemukan permasalahan sehingga informasi yang dihasilkan akan terasa kurang cepat, kurang akurat dan kurang efisien, berdasar pada hal tersebut penulis mengusulkan sistem penilaian kinerja menggunakan web dengan database MySQL. Adapun gambaran sistem usulan adalah:

1) Admin: Mengelola semua sistem dan data penilaian.

2) Karyawan: Menerima hasil penilaian.

3) HRD: Mengelola data penilaian untuk admin.

4) Presiden Direktur: Menerima Hasil Laporan Penilaian.

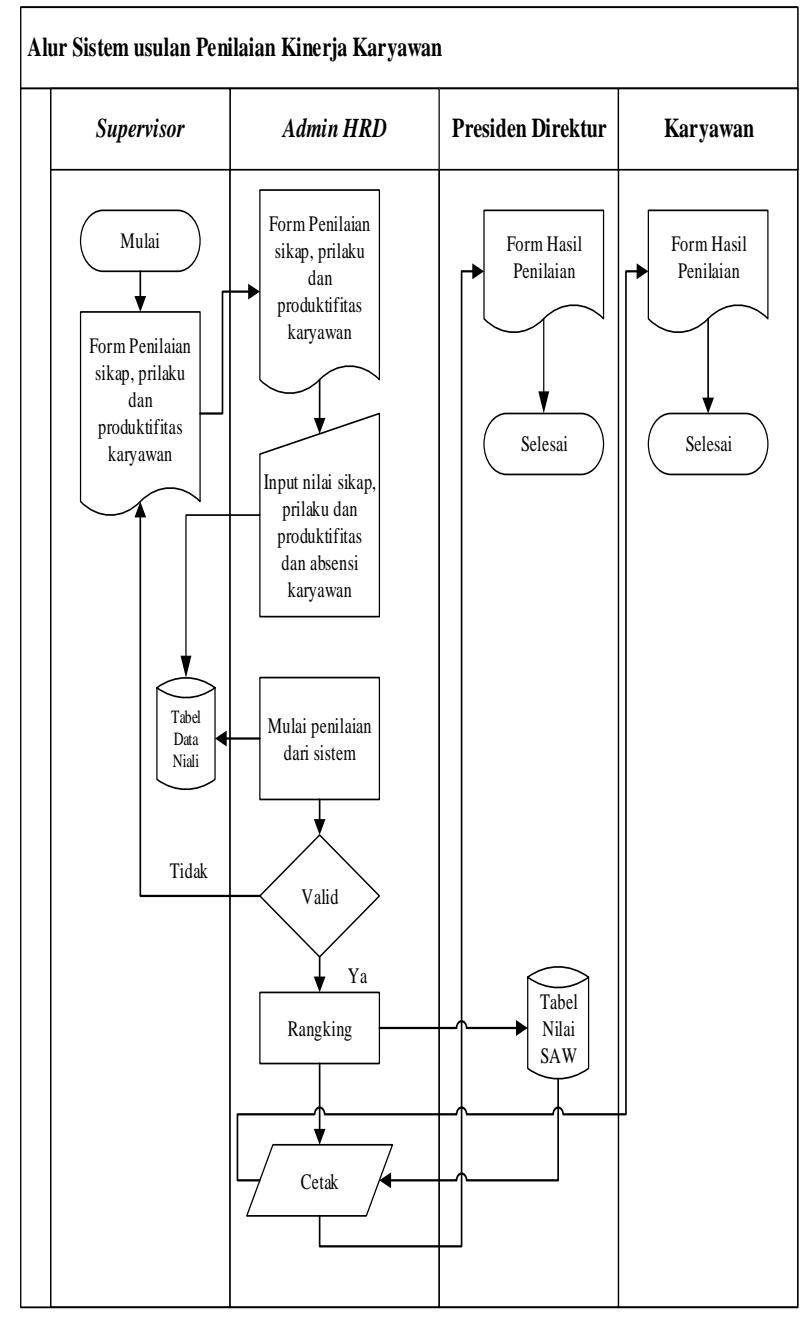

Gambar 2 Flowchart sistem usulan penilain kinerja karyawan 


\section{c. Perancangan Sistem Usulan}

1) Use Case General

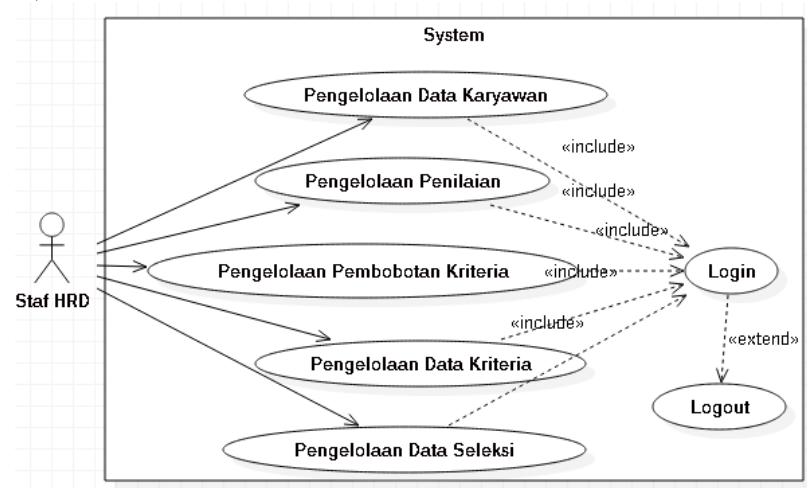

Gambar 3 Use case General

Pada gambar 3 use case general menjelaskan bahwa use case general dimana staf HRD bisa mengelola data karyawan, penilaian, pembobotan kriteria, data kriteria dan pengelolaan data klasifikasi.

\section{2) Use case Karyawan}

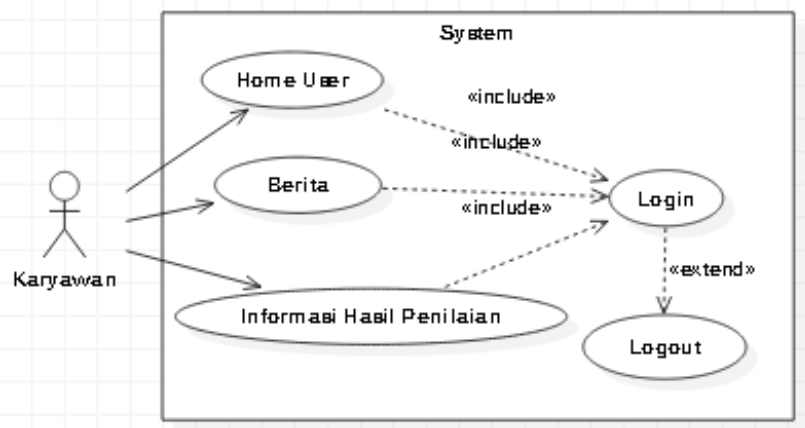

Gambar 4 Use Case User

Pada gambar 4 use case karyawan menjelaskan bahwa karyawan harus melakukan login terlebih dahulu dan setelah masuk karyawan hanya bisa melihat menu home, berita dan informasi hasil penilaian.

\section{3) Use Case Diagram Pengelolaan Data Karyawan.}

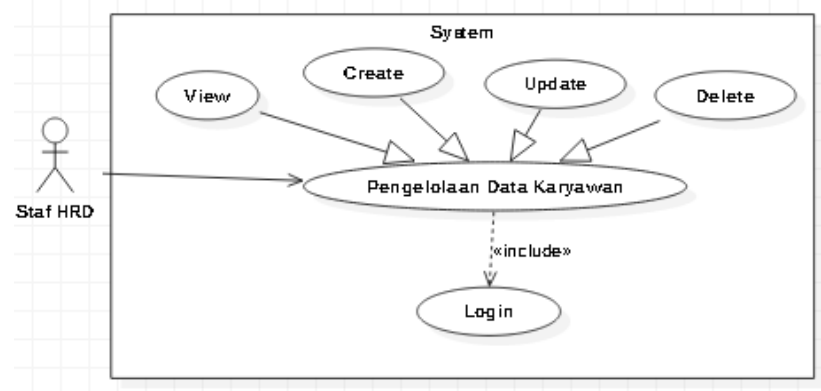

Gambar 5 Use Case Diagram Data Karyawan

Pada gambar 5 use case diagram data karyawan yaitu satf $h r d$ bertugas mengelola data karyawan yang akan di input. Pada use case ini, staf hrd bisa memasukan data karyawan, bisa update data karyawan, dan bisa hapus data karyawan.

4) Use Case Diagram Pengelolaan Penilaian

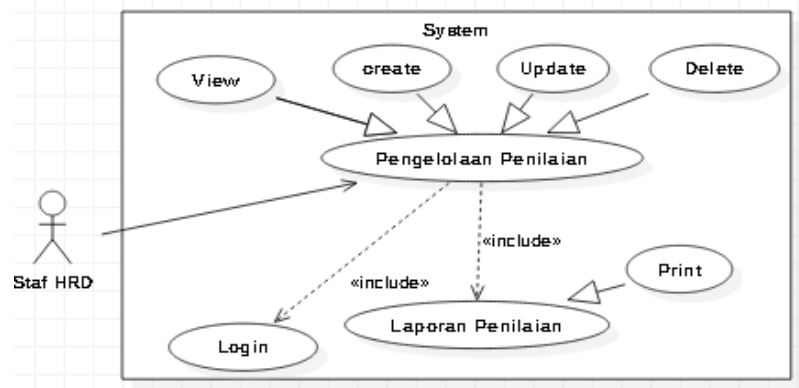

Gambar 6 Use Case Diagram Pengelolaan Data Penilaian

Pada gambar 6 use case diagram data jabatan staf hrd hanya bisa melihat data penilaian, input data penilaian, update data penilaian dan hapus data penilaian. 
5) Use Case Diagram Pengelolaan Kriteria Pembobotan

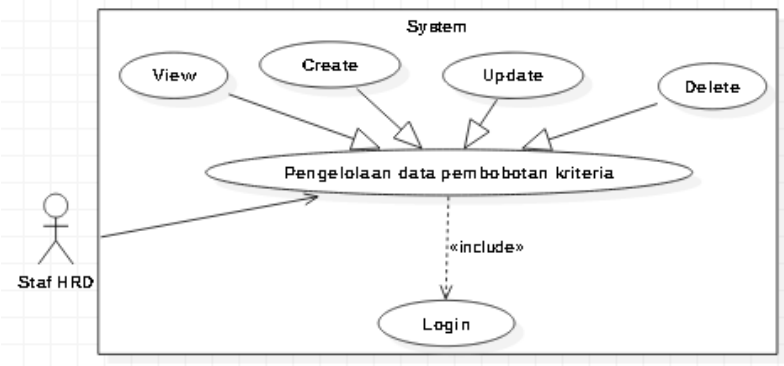

Gambar 7 Use Case Diagram Pengelolaan Kriteria Pembobotan

Pada gambar 7 use case diagram kriteria pembobotan, staf hrd setelah login hanya bisa melakukan proses pengelolaan data pembobota kriteria dengan bisa melihat data pembobotan, memasukan data pembobotan, update data pembobotan kriteria, dan hapus data pembobotan kriteria.

6) Use Case Diagram Data Kriteria

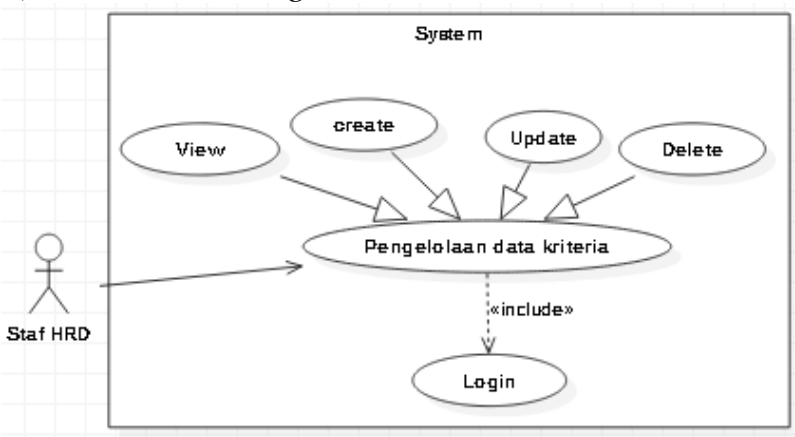

Gambar 8 Use Case Diagram Data Kriteria

Pada gambar 8 staf HRD bertugas mengelola data kriteria dengan bisa melihat, input, update, dan hapus data kriteria.
7) Use Case Diagram Pengelolaan Data Seleksi

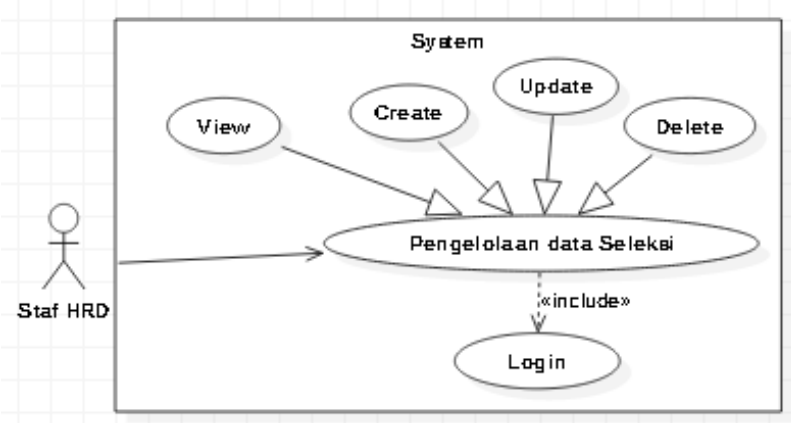

Gambar 9 Use Case Diagram Pengelolaan Data Seleksi

Pada gambar 9 staf HRD bertugas mengelola data seleksi dengan bisa melihat, input, update, dan hapus data seleksi

\section{d. Implementasi}

1) Form Register

Halaman register berfungsi untuk mendaftarkan username dan Password karyawan untuk memasuki sistem yang bertujuan supaya hanya karyawan sendiri yang mengetahui data tersebut.

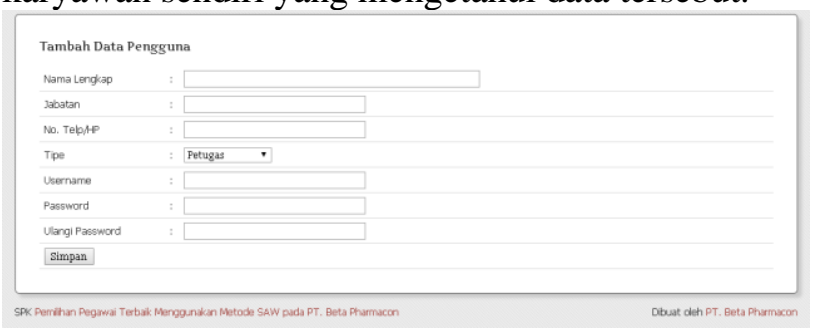

Gambar 10 Form Register

2) Form Login

Halaman login berfungsi untuk mengakses halaman selanjutnya setelah dilakukan validasi yang berupa username dan password. 


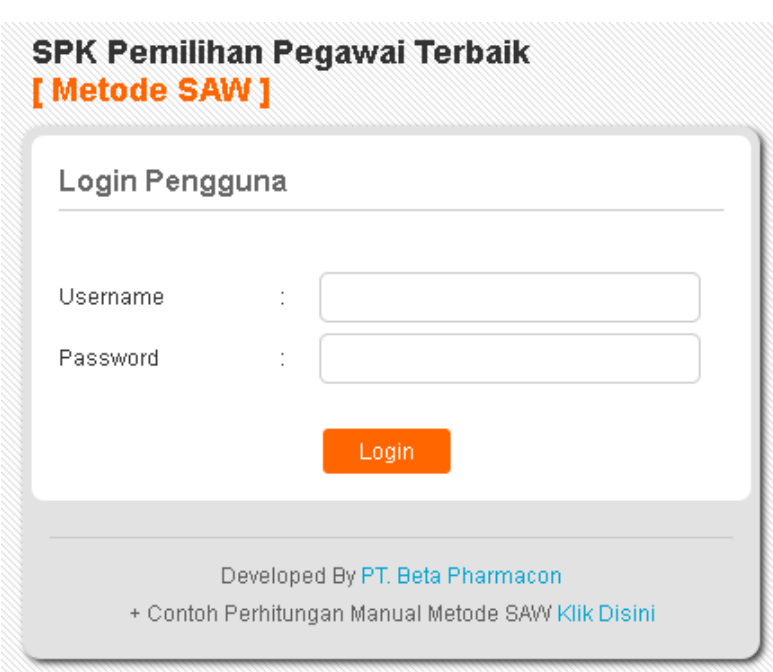

Gambar 11 Form login

\section{3) Form Menu Utama}

Halama menu utama berfungsi untuk memanggil seluruh form lainnya. Melalui form ini, aplikasi penilaian dijalankan.

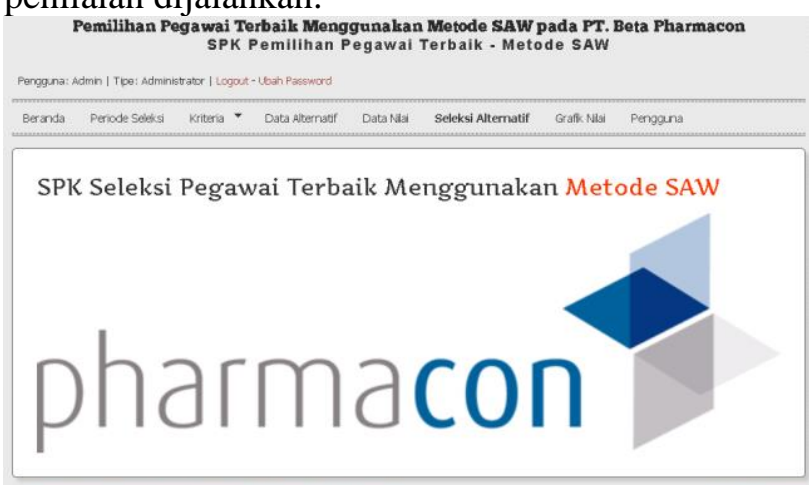

\section{Gambar 12 Form Menu Utama}

4) Form nput Periode Seleksi

Form ini akan mengisi tahun dan bulan penilaian kinerja karyawan.

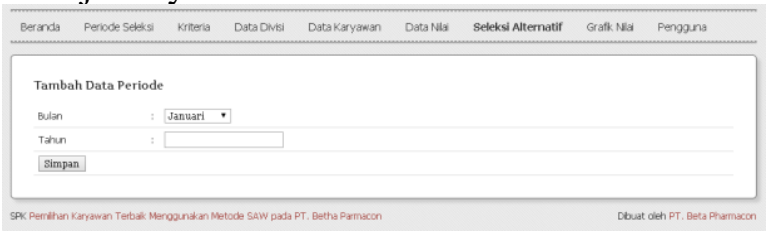

Gambar 13 Form Input Periode Seleksi

5) Form Data Periode Seleksi

Form ini akan mengelola data periode penilaian.

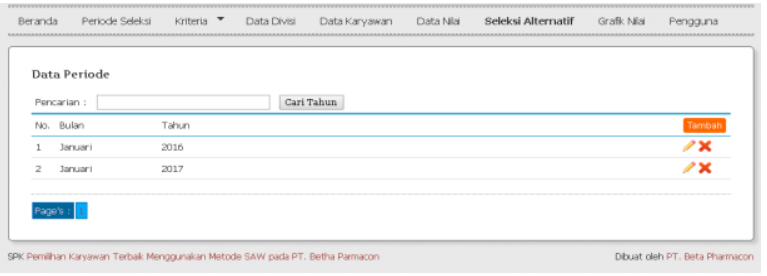

Gambar 14 Form Data Periode Seleksi

6) Form Input Karyawan

Halaman form Input data karyawan berfungsi untuk memasukan data karyawan.

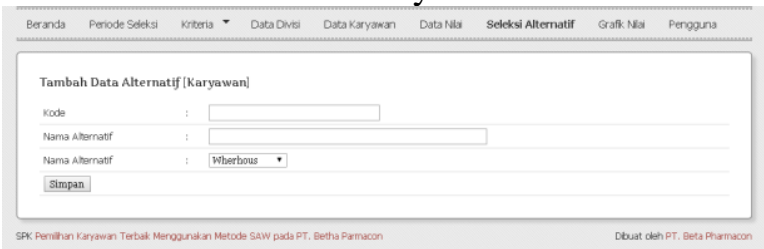

\section{Gambar 15 Form Input Karyawan}

7) Form Data Karyawan

Halaman form data karyawan akan mengelola data karyawan.

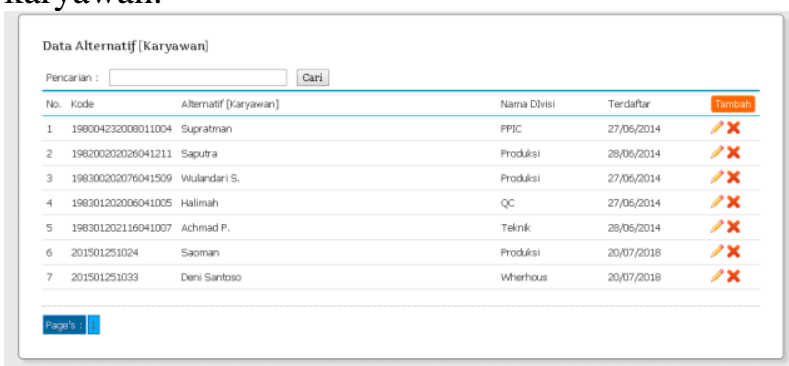

\section{Gambar 16 Form Data Karyawan}

8) Form Input Divisi

Halaman form input divisi akan memasukan nama divisi.

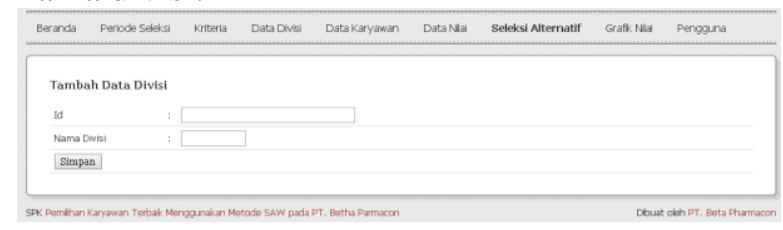

\section{Gambar 17 Form Input Divisi}

9) Form Data Divisi

Halaman form ini akan mengelola data divisi.

Jurnal Interkom: Jurnal Publikasi Ilmiah Bidang Teknologi Informasi dan Komunikasi

Volume 15 Nomor 03 Bulan Oktober - Tahun 2020 


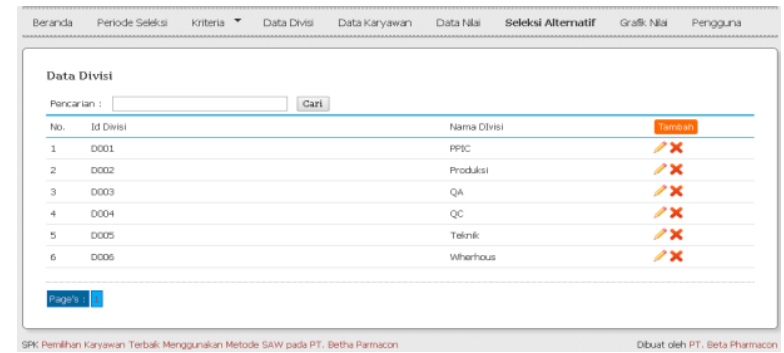

Gambar 18 Form Data Divisi

\section{0) Form Input Kriteria}

Halaman form ini akan mengisi kriteria penilaian.

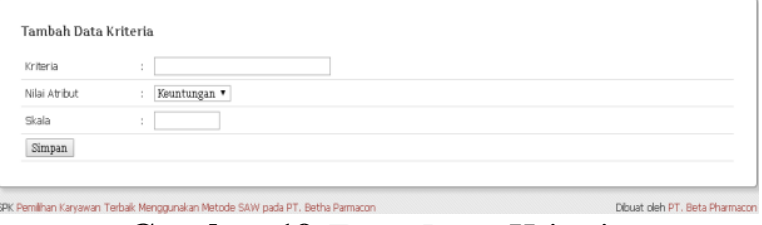

\section{Gambar 19 Form Input Kriteria}

11) Form Data Kriteria

Halaman form ini yang akan mengelola data kriteria penilaian.

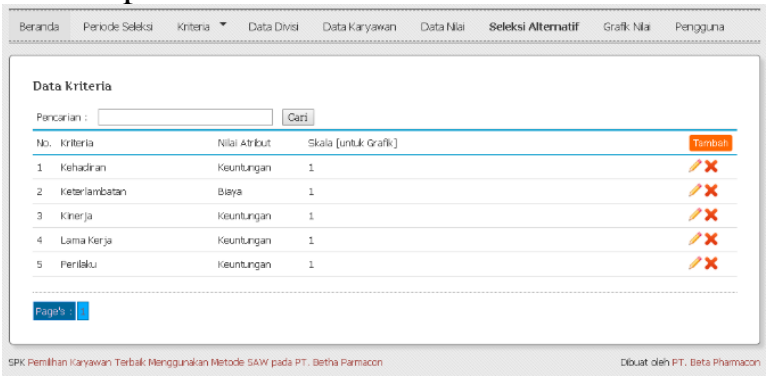

Gambar 20 Form Data Kriteria

12) Form Input Bobot Kriteria

Halama ini yang akan memasukan nilai bobot kriteria.

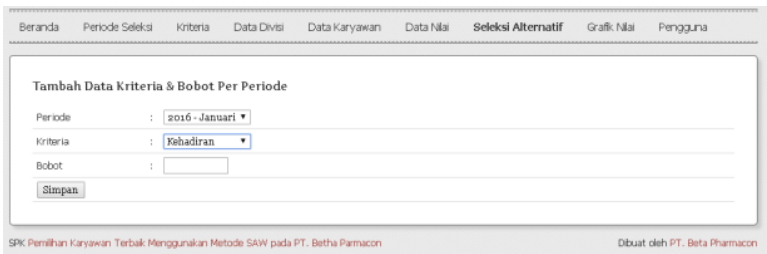

Gambar 21 Form Input Bobot Kriteria

13) Form Data Bobot Kriteria

Halaman ini yang akan mengelola data bobot kriteria.

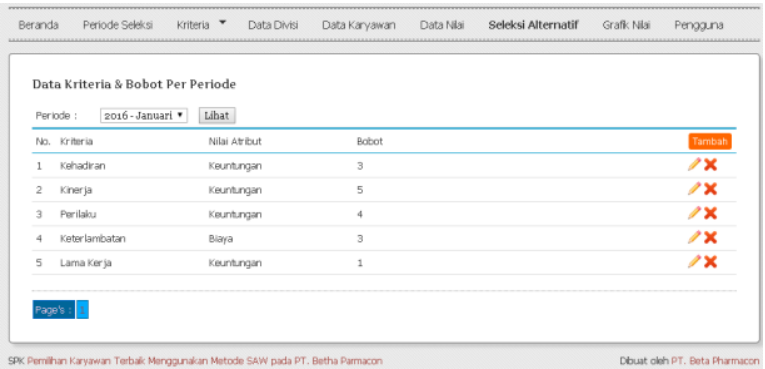

Gambar 22 Form Data Bobot Kriteria

14) Form Input Nilai

Halaman form ini akan mengisi nilai kinerja karyawan.

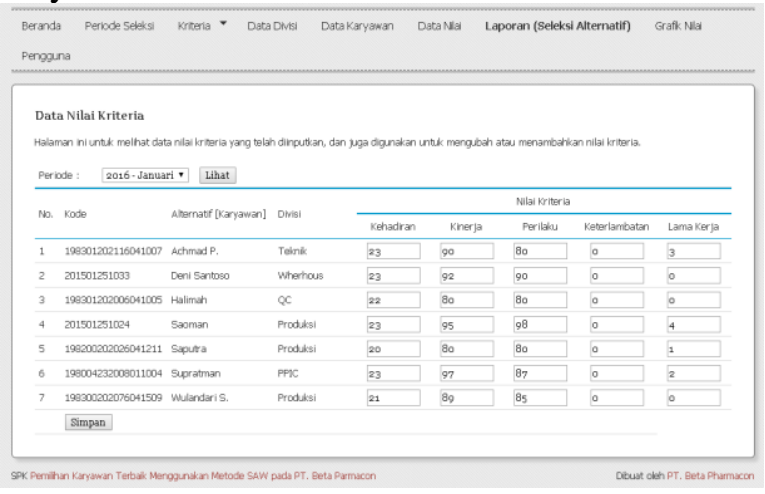

Gambar 23 Form Input Nilai

15) Form Laporan

Halaman Form ini akan menghasilkan laporan hasil penilaian yang sudah di rangking.

Jurnal Interkom: Jurnal Publikasi Ilmiah Bidang Teknologi Informasi dan Komunikasi

Volume 15 Nomor 03 Bulan Oktober - Tahun 2020 


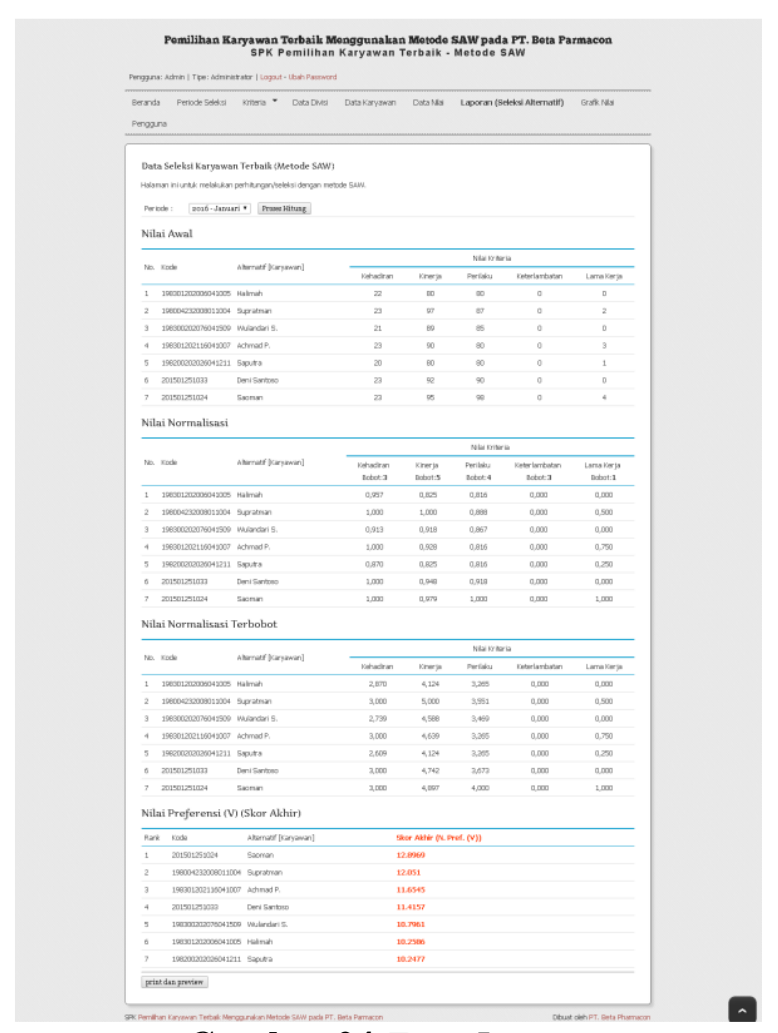

Gambar 24 Form Laporan

16) Form Grafik Nilai

Halaman ini akan menampilkan grafik nilai.

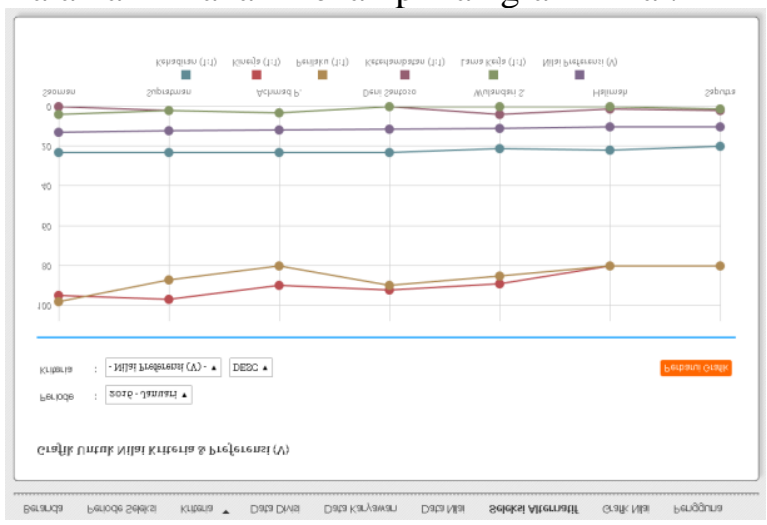

Gambar 25 Grafik Nilai

\section{Kesimpulan dan Saran}

\section{a. Kesimpulan}

Berdasarkan hasil analisis yang telah dilakukan maka penulis dapat mengambil kesimpulan bahwa sistem penilaian kinerja karyawan yang sedang berjalan masih menggunakan sistem konvensional sehingga mengakibatkan proses penilaian kinerja karyawan masih kurang optimal, oleh karena itu dengan sistem baru yang dibuat diharapkan dapat mendukung pembenahan sistem penilaian kinerja karyawan di PT Beta Pharmacon menjadi lebih baik. Pengolahan data penilaian kinerja karyawan menjadi lebih cepat karena adanya sistem yang terkomputerisasi. Seluruh data-data yang berkaitan dengan sistem penilaian kinerja karyawan akan tersimpan di dalam database dengan kapasitas daya tampung yang besar sehingga data-data yang telah tersimpan tersebut akan aman, efektif, dan efisien serta menghindari terjadinya duplikasi data. Serta ari adanya sistem penilaian kinerja ini, bisa memudahkan perusahaan dalam memberikan sebuah keputusan untuk penghargaan kepada karyawan yang terbaik.

\section{b. Saran}

Berdasarkan kesimpulan diatas, penulis memberikan saran yakni sebagai, kelemahan dari sistem penilaian kinerja karyawan dengen metode simple additive weighting (SAW) adalah prosesproses yang dapat dilakukan oleh sistem pendukung keputusan biasanya tergantung pada kemampuan perangkat lunak yang digunakan. Sistem metode SAW juga harus selalu diadakan perubahan secara berkelanjutan untuk menyesuaikan dengan kondisi yang semakin modern. Maka penulis mengharapkan pada penelitian atau pengembangan perangkat lunak selanjutnya agar membangun sebuah sistem yang bisa lebih baik.

\section{Daftar Pustaka}

P. Irawan, D. A. P. Prasetya, and P. Sokibi, "Rancang Bangun Sistem Pengarsipan Surat Kedinasan Berbasis Web Menggunakan Framework Codeigniter," $J$. Manaj. Inform. dan Sist. Inf., vol. 3, no. 2, 
pp. $157-165,2020$.

[2] H. F. Siregar and N. Sari, "Rancang Bangun Aplikasi Simpan Pinjam Uang Mahasiswa Fakultas Teknik Universitas Asahan Berbasis Web," J. Teknol. Inf., vol. 2, no. 1, p. 53, 2018, doi: 10.36294/jurti.v2i1.409.

[3] Y. Mulyanto, Y. Karisma, and U. Maharani, "RANCANG BANGUN SISTEM MONITORING PERKEMBANGAN ANAK DI TKIT TAAMASA MEGGUNAKAN METODE SPIRAL,"vol. 2, no. 3, pp. 190-195, 2020.

[4] I. Wahyudi, S. Bahri, and P. Handayani, "Aplikasi Pembelajaran Pengenalan Budaya Indonesia," vol. V, no. 1, pp. 135138, 2019, doi: 10.31294/jtk.v4i2.

[5] F. Wongso, "Jurnal Ilmiah Ekonomi dan Bisnis,” vol. 11, no. 2, pp. 481-501, 2015.

[6] M. Audrilia and A. Budiman, "Perancangan Sistem Informasi Manajemen Bengkel Berbasis Web (Studi Kasus: Bengkel Anugrah)," J. Madani Ilmu Pengetahuan, Teknol. dan Hum., vol. 3, no. 1, pp. 1-12, 2020, doi: 10.33753/madani.v3i1.78.

[7] R. A.S and M.Shalahudin., Rekayasa Perangkat Lunak Terstruktur dan Berorientasi Objek. Bandung: Informatika Bandung. Bandung: Informatika, 2016.

[8] R. S. Teuku Fadjar Shadek, "Pengembangan Aplikasi Sistem ELearning Pada Seluruh Mata Kuliah Dengan Menggunakan Program Hypertext Prepocessor ( Php ) Dalam Rangka Peningkatan Mutu Proses Dan Hasil Pembelajaran," J. ProTekInfo, vol. 4, pp. 1-18, 2017.

[9] L. Rozana, R. Musfikar, and P. T. Informasi, "Pengarsipan Surat Berbasis Web Pada Kantor Lurah," vol. 4, pp. 1420, 2020.

[10] K. Ibad, "Analisis Framing Berita Banjir oleh Humas di Website Pemerintah Kota Samarinda," eJournal Ilmu Komun., vol. 4, no. 3, pp. 520-534, 2016.
[11] Sudarmaji and A. Sari, "Sistem Informasi Website Dinamis Sebagai Media Informasi pada Kantor Camat Bangunrejo Lampung Tengah," J. Mikrotik, vol. vol.6(2), no. Lampung, pp. 1-20, 2016.

[12] G. R. F. Kawuka, P. Togas, A. Djamen, P. Teknologi, and U. N. Manado, "Perancangan Local Area Network Di Smk Negeri 1 Sinonsayang," vol. 7, no. 3, pp. $1-7,2019$.

[13] I. Wikipedia, "Jaringan area lokal," 2020. [Online]. Available: https://id.wikipedia.org/wiki/Jaringan_are a_lokal.

[14] T. R. Adianto, Z. Arifin, D. M. Khairina, G. Mahakam, and G. Palm, "Di Perumahan Menggunakan Metode Simple Additive Weighting ( Saw ) ( Studi Kasus: Kota Samarinda )," Pros. Semin. Ilmu Komput. dan Teknol. Inf., vol. 2, no. 1, pp. 197-201, 2017.

[15] N. Oktaviani, N. Merlina, and N. Nurmalasari, "Pemilihan Jasa Pengiriman Terbaik Menggunakan Metode Simple Additive Weighting (SAW)," J. Sist. dan Teknol. Inf., vol. 6, no. 4, p. 219, 2018, doi: 10.26418/justin.v6i4.29126. 